\author{
Rafał GAŁEK ${ }^{1}$ \\ Pawel GIL ${ }^{2}$ \\ Mariusz SZEWCZYK ${ }^{3}$ \\ Franciszek WOLAŃCZYK ${ }^{4}$
}

\title{
EFFICIENCY OF MICRO COMBINED HEAT AND POWER UNIT IN REAL CONDITIONS
}

\begin{abstract}
The article presents the results of short-term performance of small AISIN GECC60A2N cogeneration heat and power (CHP) unit classified to the micro-cogeneration. Electric and heat generation efficiency has been assumed as parameters characterizing the operation of the CHP unit. Under test electrical efficiency reach about $23 \%$ and thermal efficiency about $44 \%$. Overall efficiency reached about $67 \%$. Article also includes a brief description of the hydraulic and electrical system of CHP unit.
\end{abstract}

Keywords: $\mu$ CHP system, performance, AISIN, cogeneration

\section{Introduction}

The depletion of fossil fuels resources traditionally used in power industry coupled with the constantly growing consumption of electricity - both in the developed and the developing countries - tends to look for new technological, system and organizational solutions. One of the good practices resulting in high energy efficiency is combined production of heat and power (CHP). In addition distributed power generation results in reduction of energy losses in power grid. Another good practice is using renewable energy sources for heat and/or power generation. Both renewable energy resources and significant opportunities for increase in energy efficiency exists over wide geographical areas, in contrast to other energy sources, which are concentrated in a small number of countries. Rapid deployment of using renewable energy, improvement of energy efficiency, and technological diversification of energy sources, results in economic benefits and significant rise of energy security. Usage of renewable energy and CHP units reduce environmental pollution and improve public health also.

\footnotetext{
${ }^{1}$ Rafał Gałek, Rzeszow University of Technology, e-mail: rafalgalek@prz.edu.pl

2 Corresponding author/autor do korespondencji: Paweł Gil, Rzeszow University of Technology, 8 Powstańców Warszawy Ave., 35-959 Rzeszów, tel.: (17) 7432299, e-mail: gilpawel@ prz.edu.pl

3 Mariusz Szewczyk, Rzeszow University of Technology, e-mail: szewmar@ prz.edu.pl

${ }^{4}$ Franciszek Wolańczyk, Rzeszow University of Technology, e-mail: fwolan@prz.edu.pl
} 
Cogeneration heat and power unit generates electricity and useful heat at the same time. Cogeneration is a very efficient use of fuel from thermodynamic point of view. In separate production of electricity, some amount of energy must be discarded as waste heat, but in cogeneration systems some amount of this wasted thermal energy is put to use. Micro combined heat and power ( $\mu \mathrm{CHP})$ units are intended to be used as distributed energy sources. The $\mu \mathrm{CHP}$ installations are usually less than $5 \mathrm{~kW}$ electrical power and they are intended primarily for houses or small businesses. Instead of burning fuel to merely heat space or water, some of the energy is converted to electricity in addition to heat. This electricity can be used within the house or business or, if permitted by the grid management, sold back into the electric power grid. A detailed experimental investigation of instantaneous performance of micro CHP unit was presented in $[1,2]$. Although the degree of dissemination of the CHP technology varies depending on the country, the industrial and district CHP plants have an important and well-established role in the power systems of many countries [3].

Cogeneration heat and power units consist of four basic elements: a prime mover (engine or drive system), an electricity generator, a heat recovery system, and a control system. The prime mover, while driving the electricity generator, creates usable heat that can be recovered. In electrical output terms, CHP units sizes range from $1 \mathrm{kWe}$ (kilowatt electric) to over $1000 \mathrm{MWe}$ (megawatt electric). Micro CHP ( $\mu \mathrm{CHP})$ installations use five different technologies: microturbines, internal combustion engines, Stirling engines, closed cycle steam engines and fuel cells. Theoretically, almost any fuel is suitable for micro and mini CHP for example diesel, LPG or biogas, although for new systems, natural gas currently predominates.

The aim of the article is presentation of the performance of micro cogeneration unit under the real working conditions.

\section{Experimental setup}

Investigated micro CHP unit is part of a system consisting moreover photothermal and photovoltaic solar system, two heat pumps: compressor and absorption type and mid-term heat accumulator operated in the Solar and Environment Thermal Energy Laboratory in Department of Thermodynamics in Rzeszow University of Technology. The way each device producing electrical and/or thermal energy works is related to determinants resulting from the structure of the heat sinks and their characteristics. System is controlled by the master control system automatically implementing the tasks of acquisition and presentation of a measurement data. A CHP AISIN GECC60A2N with nominal electric power of $6 \mathrm{~kW}$ and a thermal output of $11.7 \mathrm{~kW}$ (Fig. 1a), is used in the system. It is equipped with three-cylinder internal combustion engine with OHV timing with a capacity of $952 \mathrm{~cm}^{3}$ burning natural gas. Main parameters of CHP unit (Fig. 1b) are presented in Tab. 1. 
a)

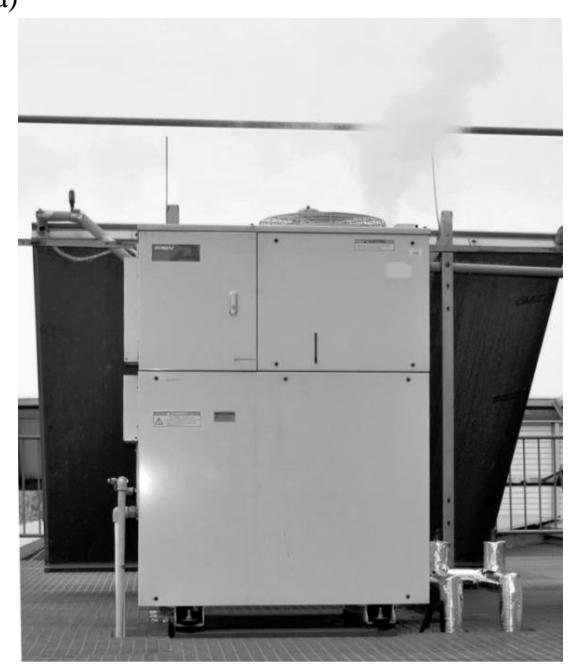

b)

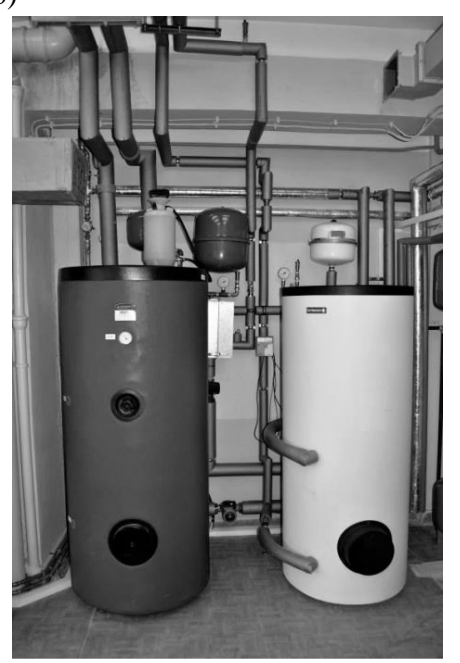

Fig. 1. CHP AISIN GECC60A2N (a) unit installed on roof, CHP heat sinks (b)

Table 1. Cogenerating unit AISIN GECC60A2N [4]

\begin{tabular}{|l|c|}
\hline Company & AISIN \\
\hline Type & GECC60A2N \\
\hline Rated electrical output & $6 \mathrm{~kW}$ \\
\hline Heat Recovery & $60 \rightarrow 65^{\circ} \mathrm{C}$ \\
\hline Output hot water temperature & $20.8 \mathrm{~kW}$ \\
\hline Fuel gas consumption rate & $54 \mathrm{~dB}$ \\
\hline Noise level & Natural gas \\
\hline Fuel gas type & $952 \mathrm{~cm}{ }^{3}$ \\
\hline Internal combustion engine - Water cooled, Vertical, 4-cycle, 3 cylinders, Lean-burn \\
\hline Displacement & $1600-1800 \mathrm{rev} / \mathrm{min}$ \\
\hline Rated revolution rate & $28.8 \%$ \\
\hline Permanent magnet type, 16 poles, synchronous generator & $85 \%$ \\
\hline Efficiency of electricity generation & $56.2 \%\left(60 \rightarrow 65^{\circ} \mathrm{C}\right)$ \\
\hline Efficiency of heat generation & \\
\hline EUF & \\
\hline
\end{tabular}

Combustion engine used in $\mu \mathrm{CHP}$ unit drives three-phase synchronous generator. The electrical current is then rectified and subsequently led to the inverter adjusting the parameters of the generated electricity to the requirements of the grid and synchronizing itself with the grid. This allows the connection of cogenerating unit to the building electrical installation. At the output of CHP electricity has parameters used in the Japanese standard low voltage network, which is 
100/200 V supplied with 3 wires. This dictates the need for additional external transformer. An integrated control system and air cooler allow the CHP unit production of the electricity independently from the current heat demand and working with a fraction of the nominal power matching the needs of consumers in a separated circuit. Second mode of operation allows running CHP on heat demand generated electricity is transmitted to common building electric network. Heat is recovered from engine and transported to hot water tanks. The working fluid is propylene glycol solution.

Diagram of the hydraulic system transferring heat from the CHP unit to heat sinks is presented in Fig. 2. Cogeneration heat and power unit can transfer heat to heating system of the building - this is the main goal - or to domestic hot water tank with a capacity of $500 \mathrm{dm}^{3}$ (Fig. 1b). Glycol solution heated in the cogenerator passes first through the plate heat exchanger (Fig. 2). Transmission of heat in a plate heat exchanger (W) to the boiler water circulation is switched on by setting the three-way valve $(Z)$ in the open position what establish flow of water through it. Heat transfer to the domestic hot water tank is done through two coils connected in series. Boiler water entering the plate heat exchanger is pre-heated by the absorption heat pump to the temperature of $40-45^{\circ} \mathrm{C}$. Similarly, domestic water supply tank is pre-heated by solar collectors and compressor heat pump. This solution allows obtaining the nominal temperature parameters for CHP unit which are respectively $65^{\circ} \mathrm{C}$ and $60^{\circ} \mathrm{C}$ (Tab. 1). Cogenerator is mounted on the building roof (Fig. 1a), as it is designed to work under atmospheric conditions.

Electrical connection to the building installation is performed by a transformer and junction box containing the fuses and circuit breakers. Two electricity meters PAFAL 12EA5gr have also been used to measure electricity flows. One of them measures the energy delivered by the cogenerator to the network while the second one measures energy necessary to drive the circulation pumps. Mode of cogenerator operation is established on heat demand for. As it is not possible to adjust the thermal power of the cogenerating unit, it has a binary character. Cogenerator can be on - works all the time with a nominal power - or off. The decision to start CHP unit is taken on the basis of the temperatures in the hot water tank (T5), in the domestic water tank and at the return pipe of heating system in the building. Priority of domestic hot water for valve $(Z)$ is implemented. At such control mode cogenerator works all the time with a nominal electrical power equal to $6 \mathrm{~kW}$, and all generated electricity is transmitted to the building electric network and consumed in situ.

Switching on/off the CHP unit and controlling the three-way valve is done via relay output cards placed in Keithley 3706 measurement system acting a role of both the multimeter and the controller. Keithley 3706 measurement system supports totally tens of inputs (mainly resistance thermometers) and several outputs to control pumps and valves in the laboratory ensuring measurement and control of all connected energy subsystems. It is connected to a computer through the 
USB bus. Computer runs the control program responsible for acquisitioning measurement data, making decisions on the basis of the inputs, controlling outputs, and the acquisition and presenting the results.

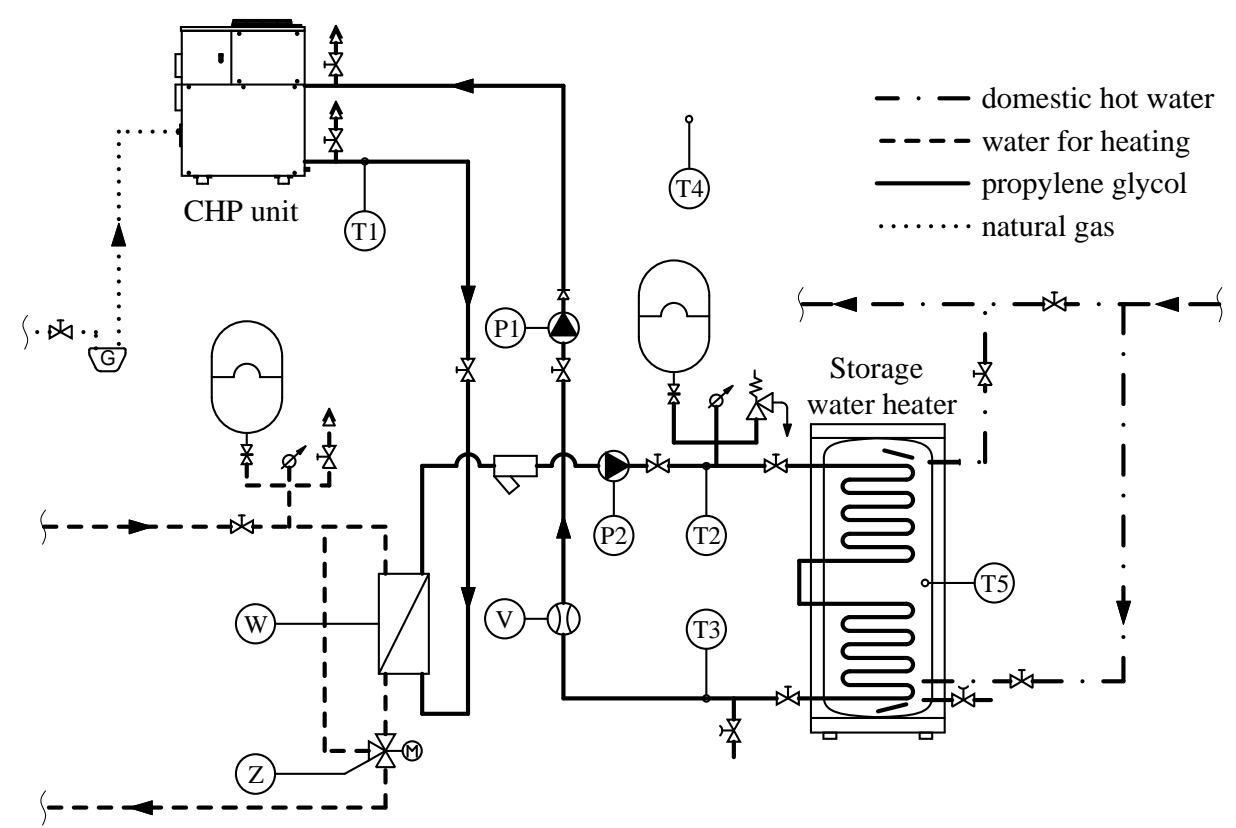

Fig. 2. Diagram of the hydraulic system, $\mathrm{G}$ - gas meter, $\mathrm{T} 1$ - glycol solution temperature at the CHP outlet, T2 - temperature at the inlet to the hot water tank coils, T3 - temperature at the outlet of the hot water tank coils, T4 - ambient temperature, T5 - temperature in the hot water tank, $\mathrm{V}$ - heat meter, $\mathrm{W}$ - plate heat exchanger, $\mathrm{Z}$ - mixing valve, $\mathrm{P} 1$ - force pump, P2 - suction pump

\section{Measurements}

For the acquisition and presentation of data on the basis of which the characteristic parameters of the cogenerator were determined the system composed of Keithley 3706 measurement system and LabView based application was used. Glycol solution temperature (T1), ambient temperature (T4), and the temperature of the coolant in the internal circuit of CHP units were measured by the CHP integrated electronic controller connected to a computer via RS-232 serial port. Temperature at the inlet and outlet of the domestic hot water tank coils (T2 and T3) and the volume flow of a glycol solution were received from the heat meter Kamstrup MULTICAL 402. The hot water tank temperature (T5) was measured by Keithley multimeter 3706 using a silicon thermistor KTY-81. All these readings were recorded automatically with one minute interval. Readings of electricity meters and gas meter PAFAL 12EA5gr INTERGAZ BK-G4M were made manually every 10 minutes. 
The total thermal power of the CHP was calculated using the supply and return temperature (T1) and (T3), but unfortunately, due to the lack of a temperature sensor near the connecting pipe at return to cogenerator, CHP power calculated this way is slightly less than the actual power. This disagreement in CHP thermal power is equal to the thermal loses on the piping between the CHP connecting pipe and the temperature sensor (T3) but hydraulic pipes connecting the cogenerator with the domestic hot water tank are thermally insulated so it can be neglected. For the power calculations specific heat of $40 \%$ glycol solution at mean temperature equal to the arithmetic mean (T1) and (T3) were taken [5]. The value of glycol solution density was determined for the return temperature (T3). The amount of heat delivered to the domestic hot water tank was calculated similarly using values of temperature (T2) and (T3).

Electrical efficiency was determined based on the instantaneous electric power cogenerator (gross) and the power actually delivered to the building electric network (net). To calculate the efficiency of the device following formulas were used [3]:

- electrical (electric generation) efficiency:

$$
\eta_{e l}=\frac{N_{e l}}{E_{c h}}, \%
$$

- thermal (heat generation) efficiency:

$$
\eta_{c}=\frac{\dot{Q}}{E_{c h}}, \%
$$

- total efficiency (energy utilization factor):

$$
E U F=\frac{N_{e l}+\dot{Q}}{E_{c h}}, \%
$$

where: $N_{e l}$ - electrical power, $\mathrm{kW}$,

$E_{c h}$ - flux of chemical energy of fuel, $\mathrm{kW}$,

$\dot{Q}$ - thermal power, kW.

Flux of the chemical energy of fuel was calculated using the gas meter INTERGAZ BK-G4M and the lower heating value of natural gas $\mathrm{LHV}=35.75 \mathrm{MJ} / \mathrm{Nm}^{3}$ (value given by the PGNiG Laboratory).

The measurements were carried out within a few hours on the day when the full load of the cogenerator had been expected and many hours of continuous work of CHP unit had been anticipated. For the purpose of comparison, the parameters of the system control were set so that on the input and output pipe of the cogenerator values of the temperatures similar to the nominal values given by the pro- 
ducer in Tab. 2 were established for the time as longer as possible. The variation of major temperatures characterizing the work of a co-generator during the day is shown in Fig. 3.

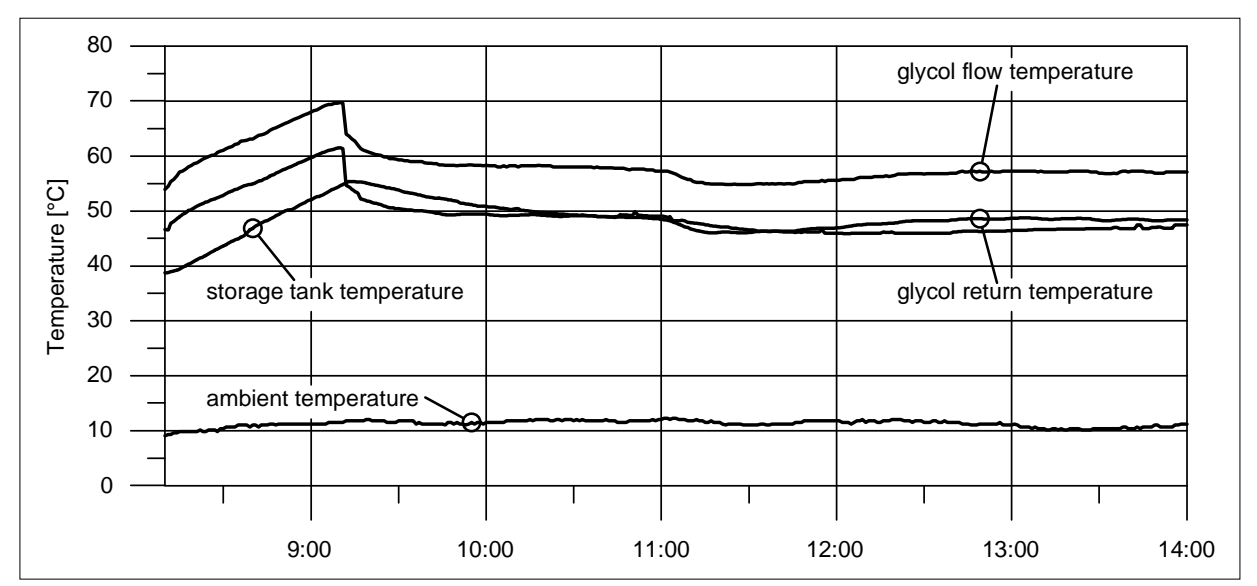

Fig. 3. The course of variability of significant temperatures

The temperature course is fundamentally determined by the morning start of heating the domestic hot water tank which had been cooled down during the night and switching position of the three-way valve $(Z)$. The changes in total thermal power generated by CHP unit and thermal power for the domestic hot water storage tank are shown in Fig. 4. Due to the specificity of the hydraulic system forcing the serial flow though plate heat exchanger (space heating) and coils in the domestic hot water tank, it can be noticed that the hot water tank temporarily works as a heat storage transferring part of stored thermal energy through the cogenerator circuit to the heating system of the building.

Electrical efficiency value does not exhibit significant volatility due to the continuous operation with a nominal power. The power output of the inverter was maintained at $6 \mathrm{~kW}$, and this value was used to determine the gross electrical efficiency, which amounted to approx. $26.3 \%$. The power delivered to the grid, however, was significantly lower and amounted to only $5.32 \mathrm{~kW}$ and in consequence net electrical efficiency was lower as shown in Fig. 5. This difference resulted from the need to power circulation pumps $(200 \mathrm{~W}$ - the result of measurement), internal automation systems and electronics integrated inside cogenerator (210 W - manufacturer's data). 


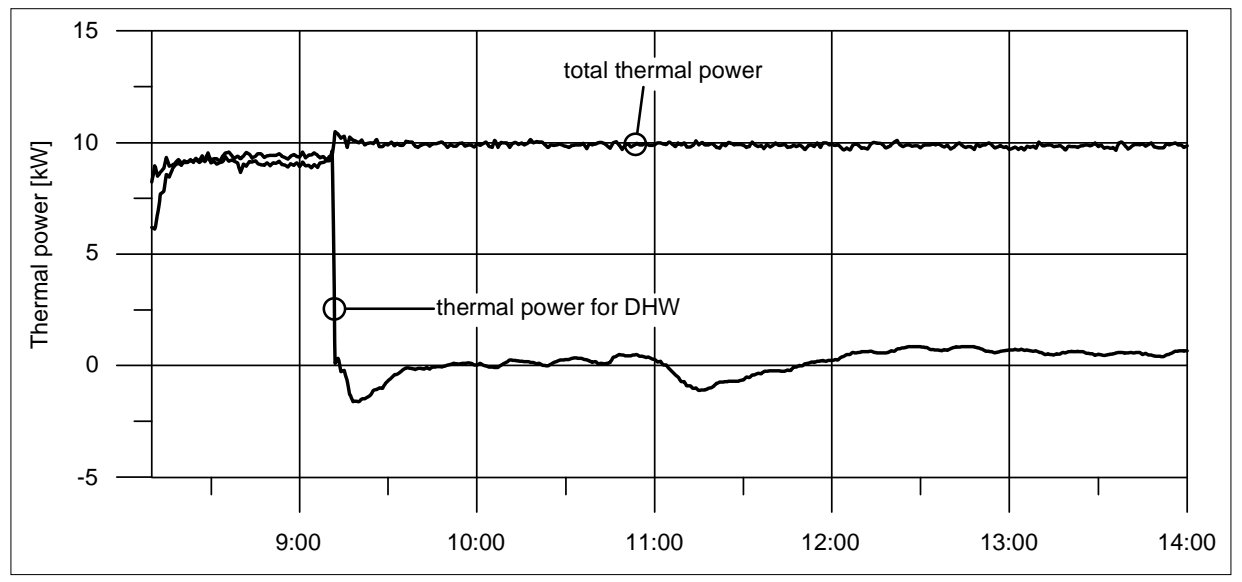

Fig. 4. The course of total thermal power generated by CHP and thermal power transferred to the domestic hot water tank

The electric energy balance closes the unavoidable losses of the transformer whose efficiency on the basis of the above data can be determined at about $95.5 \%$. On the basis of the power returned to the grid, the net electrical efficiency was calculated - approx. 23.3\%. The calculated gross electric efficiency is lower than the value specified by the manufacturer of $28.8 \%$ due to slightly higher than nominal actual stream of chemical energy of fuel.

Changes of the thermal efficiency are determined by the course of the total heat power generated by CHP unit and its value exceeds $45 \%$ only for a very short period. The actual thermal efficiency values are far below the manufacturer's declared value of 56\%. The average value of the actual thermal efficiency is about $23 \%$ lower than the declared one. Considering the relatively constant consumption of fuel and almost constant electric power, the course of total efficiency (EUF) is determined by the course of heat power variability (Fig. 5). The above reasons cause that also the chemical energy use factor does not reach the declared by the manufacturer value of $85 \%$.

A summary of the basic performance indicators for several cogeneration units in the $5 \mathrm{~kW}$ electric power class is presented in Fig. 6 . It should be noticed that for devices other than the tested co-generator, the data come from the promotional materials of the producers, therefore they probably correspond to the maximum values achieved only in favorable conditions. However, even in this case, the actual value of the AISIN GECC60A2N cogeneration is one of the best in its class. Significantly lower value of thermal efficiency in comparison to other units can be explained by profiling of the device for electricity generation (even for nominal temperatures the thermal efficiency is only 56\%) and conditions of work during the experiment deviating from nominal values. 


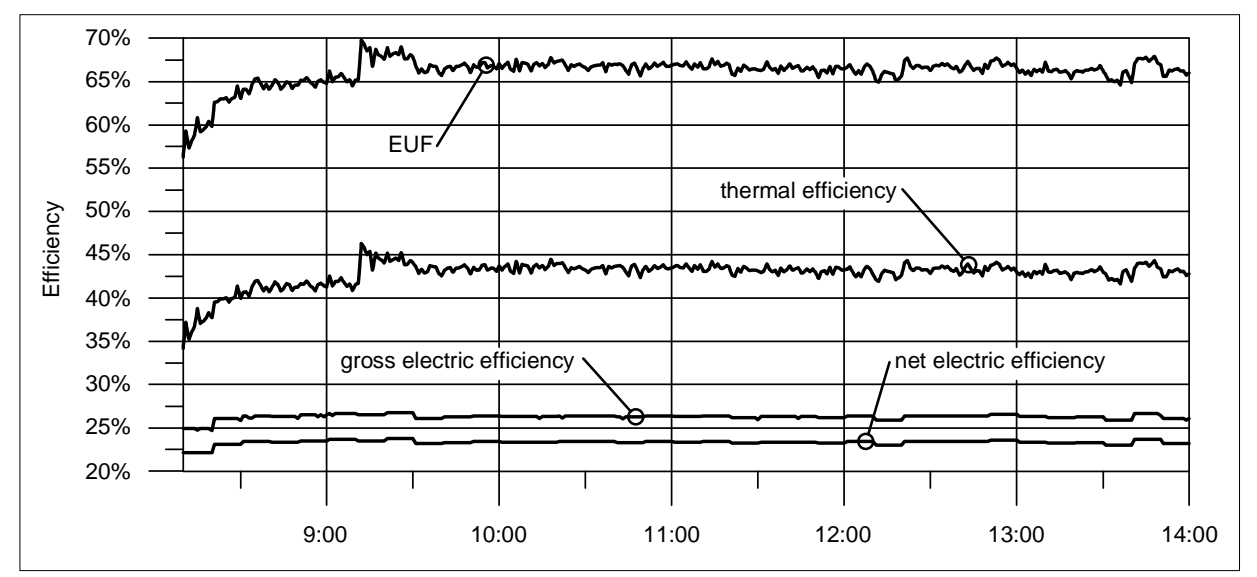

Fig. 5. The electrical, thermal and total efficiency

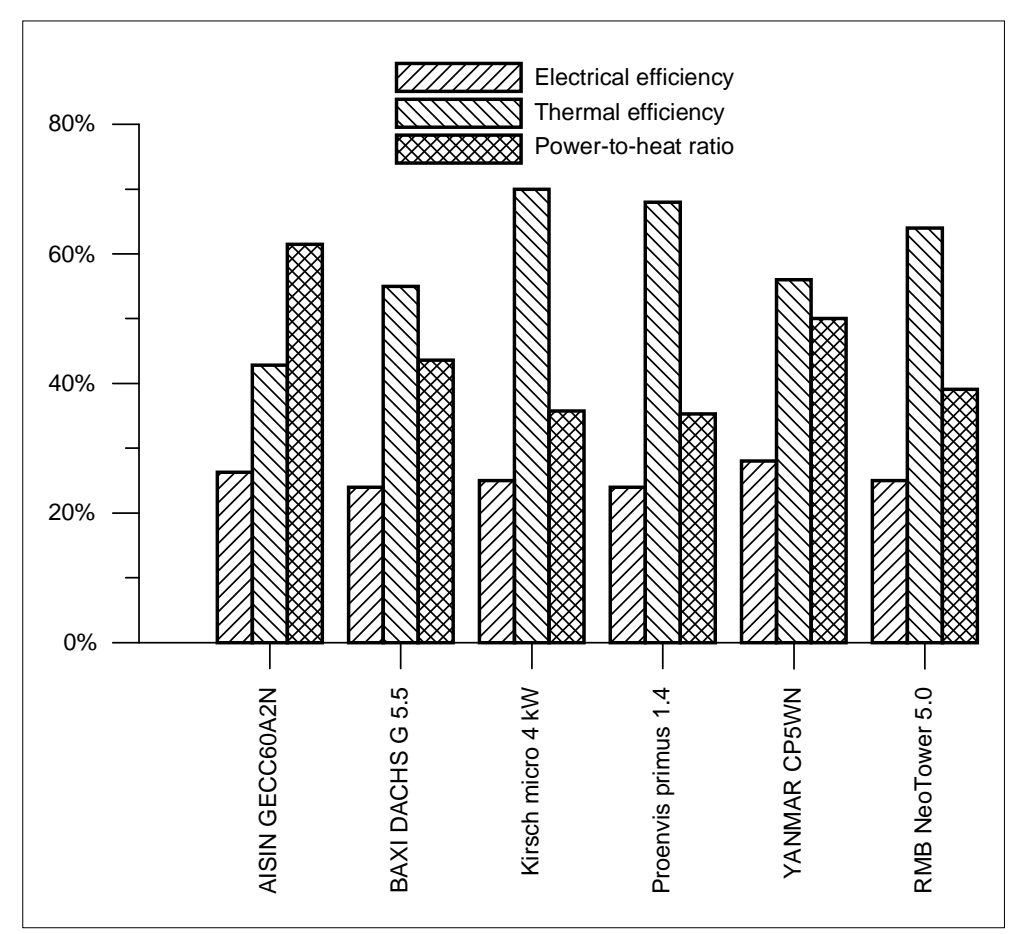

Fig. 6. Comparison of the efficiency and coefficient of association of cogeneration units with the electric power of approx. $5 \mathrm{~kW}$ 


\section{Summary}

Gross electrical efficiency equal to $26.3 \%$ should be considered satisfactory, as it is higher than the corresponding parameters of most similar units commercially available [6-8] but in real operating conditions without special adjustment of operating parameters is clearly lower than the value $28.8 \%$ given by the manufacturer, Table 1 . The electrical efficiency can probably be increased by adjusting the fuel consumption closer to level declared by the manufacturer.

The value of thermal efficiency depends largely on the characteristics of the system of heat sinks. In spite of adjusting the operating parameters of the installation in such a way that actual installation should as good as possible establish the assumed temperatures on the CHP supply and return pipe the thermal efficiency value slightly lower than $43 \%$ is clearly lower than the value given by the manufacturer $-56 \%$. It can be clearly seen that the manufacturer presents the value that is possible to achieve only in laboratory conditions. In every actual installation, this parameter will be lower and this conclusion probably applies to all manufacturers. The main way for future modification in order to increase thermal efficiency is increasing the flow rate of glycol solution in circulation. For the stability of the installation work and to avoid unwanted heat removal from the domestic hot water tank, the temperature set in it should be as close as possible to the temperature in the boiler water tank.

\section{References}

[1] Gil P., Tychanicz M., Wilk J.: Instalacja skojarzonego wytwarzania ciepła i energii elektrycznej ( $\mu \mathrm{CHP})$ - badania eksperymentalne parametrów energetycznych, Rynek Energii, 126 (2016) 49-57.

[2] Gil P., Wilk J.: Instalacja CHP z silnikiem spalinowym zasilanym gazem drzewnym, ZN PRz Mechanika, 32 (2015) 217-226.

[3] Skorek J., Kalina J.: Gazowe układy kogeneracyjne, WNT, Warszawa 2005.

[4] Gas Engine Cogeneration System Interconnection with Power Grid System Type, Operation Manual, GECC60A2 N AISIN Toyota group, 2006.

[5] 2009 ASHRAE HANDBOOK: Fundamentals.drseg.

[6] Materiały promocyjne firm: Baxi SenerTec, Kirsch GmbH, Proenvis GmbH \& Co, Yanmar, RMB/Energie GmbH.

[7] Mago P.J., Chamra L.M., Moran A.: Modelling of micro-cooling, heating, and power (micro-CHP) for residential or small commercial building applications, ASME paper IMECE2006-13558, 2006.

[8] Rosato A., Sibilio S.: Energy performance of a micro-cogeneration device during transient and steady-state operation: experiments and simulations, Appl. Therm. Eng., 52 (2013) 478-491. 


\section{SPRAWNOŚĆ MAŁEGO UKŁADU KOGENERACYJNEGO PRACUJĄCEGO W RZECZYWISTYCH WARUNKACH}

\section{Streszczenie}

W artykule przedstawiono krótkookresowe wyniki pomiarów sprawności małej jednostki kogeneracyjnej AISIN GECC60A2N zaklasyfikowanej do mikrokogeneracji ( $\mu$ CHP). Sprawność wytwarzania energii elektrycznej i ciepła została przyjęta jako parametry charakteryzujące pracę układu kogeneracyjnego. Rzeczywista sprawność elektryczna osiąga wartość około 23\%, a sprawność cieplna - wartość około 44\%. Sprawność całkowita osiągnęła 67\%. Artykuł zawiera krótki opis układu hydraulicznego i elektrycznego jednostki kogeneracyjnej.

Słowa kluczowe: system $\mu \mathrm{CHP}$, sprawność, kogeneracja, energia odnawialna

DOI: $10.7862 / \mathrm{rm} .2018 .39$

Otrzymano/received: 17.07 .2018

Zaakceptowano/accepted: 24.11.2018 
